\title{
ガス状のホルムアルデヒドにシロイヌナズナなどの小植物体を 曝露させるためのシステムの作成
}

\author{
久保 森 $^{1} \cdot$ 杉村暢大 $^{1} \cdot$ 中桐紘治 ${ }^{1} \cdot$ 秋田 求 ${ }^{1,2} \cdot$ 泉井 桂 $^{1,2}$ \\ ${ }^{1}$ 近畿大学生物理工学部 649-6493 和歌山県紀の川市西三谷 930 \\ 2 近畿大学先端技術総合研究所 642-0017 和歌山県海南市南赤坂 14-1
}

\section{Construction of a system to expose tiny plants, such as Arabidopsis thaliana, to gaseous formaldehyde}

\author{
Shigeru KUBO ${ }^{1}$, Chotai SugIMURA ${ }^{1}$, Koji NAKAGIRI ${ }^{2}$, Motomu AKITA ${ }^{1,2}$ and Katsura IZUI ${ }^{1,2}$ \\ ${ }^{1}$ School of Biology-Oriented Science and Technology, Kinki University, \\ 930 Nishimitani, Kinokawa, Wakayama 649-6493 \\ ${ }^{2}$ Institute of Advanced Technology, Kinki University, 14-1 Minamiakasaka, Kainan, Wakayama 642-0017
}

\begin{abstract}
Formaldehyde (HCHO) is a major industrial chemical, and is a common environmental pollutant that can cause multiple chemical sensitivity and sick building syndrome. Previously, by introducing the genes for $\mathrm{HCHO}$ fixation from a methylotrophic bacterium into plants, we succeeded in conferring an augmented ability to assimilate $\mathrm{HCHO}$ onto the transformed plants. To test the feasibility of this strategy for phytoremediation, more quantitative data concerning absorption and tolerance are required. Here, we report the construction of a small system to expose plants to defined concentrations of $\mathrm{HCHO}$ under controlled humidity. Details of the flow-diagram and functional units of the system are described, and specifications of the control of $\mathrm{HCHO}$ concentration and humidity are provided. The effects of $\mathrm{HCHO}$ exposure on the wild-type and the Arabidopsis thaliana transformant were examined preliminarily using this system. Exposure to 1-2 ppm HCHO for 2 days caused visible changes on the surface of the leaves, and exposure to 14-16 ppm for 4 days caused browning and withering of the leaves. No differences were observed in the HCHO tolerance between both plants under exposure conditions used.
\end{abstract}

Keywords: exposure system, formaldehyde, genetic engineering, phytoremediation, sick building syndrome

緒言

ホルムアルデヒド（HCHO）は工業的に大量に生産され,

2014 年 8 月 13 日受付

2015 年 5 月 20 日受理

Corresponding author: Motomu Akita (akita@waka.kindai.ac.jp)
主に合成樹脂や接着剤などの合成原料として使用されてい る. 以前は HCHO が消毒剤・防腐剤などとして広く使用され てきたが, 1980 年頃からその毒性が認識されて以来, 消毒 剤などとして直接使用される機会は減少してきた. しかしなが ら, 家庭用の建材や家具などに使われる合成樹脂や接着剂 などから室内環境中に徐放された低濃度の $\mathrm{HCHO}$ に住人 が接触する機会は, 我が国では 1995 年ころまでは逆に増大 する傾向にあった. HCHO がシックハウス症候群の主要な原 因物質であることが見出されて以来, HCHO は代表的な環 
境污染物質の一つとして注目されるようになった. HCHO は, 生体に対しては強い毒性を示し, 発がん性をもつことも示され ている ${ }^{1)}$. WHO のガイドライン ${ }^{2)}$ では, 通常の生活環境とし ての室内の空気中の限度濃度は $0.08 \mathrm{ppm}(\mathrm{v} / \mathrm{v})$ 以下, HCHO を業務として取り扱う室内の限度濃度は 1 ～ 2 ppm と定められている. 我が国では 2001 年の厚生省と建設省の ガイドラインによって, 建材の作成工程に HCHO を使用するこ とが禁止されて以来, シックハウス症候群の発症頻度は顕著 に抑制されるようになったが, 未だ完全に解決されるには至っ ていない.

室内に拡散される低濃度の HCHO を持続的かつ安価に 除去する方法の一つとして観葉植物の利用が発案され, 実 際, ある種のシダ (Boston fur) やポトスなどの鉢植えが比 較的高い HCHO 吸収能を示すことが Wolverton ${ }^{3)}$ によって 見出された. しかし, その後の研究によって, この吸収が, 植 物の葉の働きによるのではなく, 主として葉の表面や地中の細 菌によることが示された ${ }^{4)}$. 我々は, 一群のメチロトローフ細菌 が HCHO をいわゆるリブロースモハリン酸経路 ${ }^{5)}$ の働きによっ て同化して炭素源とすることに注目し，この経路の酵素（へキ スロース 6-リン酸合成酵素およびへキスロース 6-リン酸イソ メラーゼ）を植物の葉緑体において発現させ，植物に $\mathrm{HCHO}$ の同化能を付与することを行ってきた ${ }^{6-8)}$. タバコおよ びシロイヌナズナにこれらの酵素の遺伝子を導入すると, 得ら れた形質転換体は培養容器内において野生株より高い $\mathrm{HCHO}$ の同化能を示し, かつ HCHO に対するより高い耐性 を示した ${ }^{7)}$. したがって, この原理を室内観葉植物などに応 用すれば, 環境浄化に役立つ可能性が示唆された ${ }^{9,10)}$.

得られた組換え植物が実際に室内空気の浄化に役立つか 否かを判定するためには, 植物の許容量や生理学的変化を 含む, より定量的な基礎的デー夕が必要である. すなわち, シ ロイヌナズナのようなモデル植物を用いて (1) 種々の濃度の HCHO が及ぼす影響を調べ, (2) 野生型と組換え植物の $\mathrm{HCHO}$ 吸収能力と吸収速度などを定量的に調べなければな らない. (1)のためには, 植物を長時間一定の湿度（以下 $R H$ と略）条件下で一定の濃度の $\mathrm{HCHO}$ に曝露するための 装置が必要である. これまでに (1) の研究として, 寒天培地 などに所定の濃度の HCHO を加えて根から HCHO を吸収 させて調べた例（例えば Chen et al. ${ }^{7}$, , Wang et al. ${ }^{11)}$ ) や, 少量の HCHO 水溶液（37\%の市販のホルマリン）をマ イクロチューブに分注しこれを閉鎖系の曝露チャンバー内に 設置して HCHOを自然拡散させた例（例えばChen et al. ${ }^{7)}$, Park et al. ${ }^{12)}$ ) などがある. これら簡易な閉鎖系では, チャンバー内の $R H$ は植物の活発な蒸散のために, 短時間 に $90 \%$ 以上に達して通常の自然環境からはずれてしまうこ と, また高湿度では葉の表面への水の凝結が容易となり, そ
の水に捕捉された HCHO によって新たに生じる作用なども無 視できなくなることなどが予想されるので, 生育条件に近い条 件下でデー夕を得るためには $R H$ を 50-70 \%に保つことが好 ましいと考えられる. いっぽう, 湿度環境も制御されたチャン バーを用いた測定例（例えば Kondo et al. ${ }^{13,14 ）}$ やXu et $\mathrm{al}^{15)}$ ) も報告されている. これらのうち, 例えば Kondo et al. による 2 報 ${ }^{13,14)}$ では, 大型（120 L）の曝露チャンバーを 使用し, チャンバー内のガス濃度は, ガスを一定時間サンプ リングしたのちに化学的に定量する方法がとられている. Xu et al. ${ }^{15)}$ による例では, 曝露チェンバー (75 L) の入口と出口に $\mathrm{HCHO}$ 濃度計を取り付け, 出入り口での濃度の差から HCHO の吸収量をリアルタイムで求めている.しかし, いず れの報告でも, 植物による HCHO の吸収・同化によって到 達し得る $\mathrm{HCHO}$ の下限濃度が求められていないなど情報に 限りがある.

これに対し我々は, 暴露装置を小型化し, かつ上記の (2) の測定を迅速かつ簡便に行うために, 曝露チャンバー内の 気体を循環させて閉鎖系とし, 系内の HCHO 濃度をリアル夕 イムでモニターすることを計画している. 本論文では, その最 初の研究として, 一定の $R H$ で一定の濃度の HCHO を含む 空気を安定的に供給する装置の構築とその性能について報 告し, 実際にシロイヌナズナの野生型および上記の組換え体 を HCHO 曝露した際の可視的影響を比較した結果を報告す る. さらに, 上記 (2) に必要なデバイスのシステムへの組み込 みについて提案する.

\section{材料および方法}

\section{HCHO 曝露装置を設置した室内の環境}

曝露装置を設置した実験室は, 空調機により夏季は 22 ${ }^{\circ} \mathrm{C}$, 冬季は $24{ }^{\circ} \mathrm{C}$ 維持した. 室内空気は換気扇の連続運転 により常時新鮮空気を建屋の廊下から供給し, 建屋外へ排出 した. なお, 測定中の室内の HCHO 濃度のモニターには, ポ ータブルホルムアルデヒド濃度測定器（ホルムアルデメータ htV, JMS）を用いた.

\section{HCHO 曝露装置}

Fig. 1A は機能ユニットの構成図を示し, 眓中の矢印は曝 露ガスの流れの方向を示す. Fig. 1Bにはその全容を示す. まず主要な構成要素について説明する。一本破線で囲まれ た Air Control Unit（特注品, 形式 ADN1-MIX, ADTEC CORPORATION）は一定の湿度に調整した空気を供給す るためのユニットであり, (6)の HCHO generator としては, U 字ガラス管（管径 $\phi=18 \mathrm{~mm}$, 管長 $=150 \mathrm{~mm}$, アズワン） にパラホルムアルデヒド $5 \mathrm{~g}$ （ナカライテスク）を充填し, 恒温

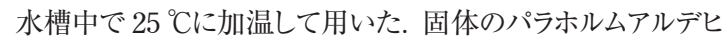




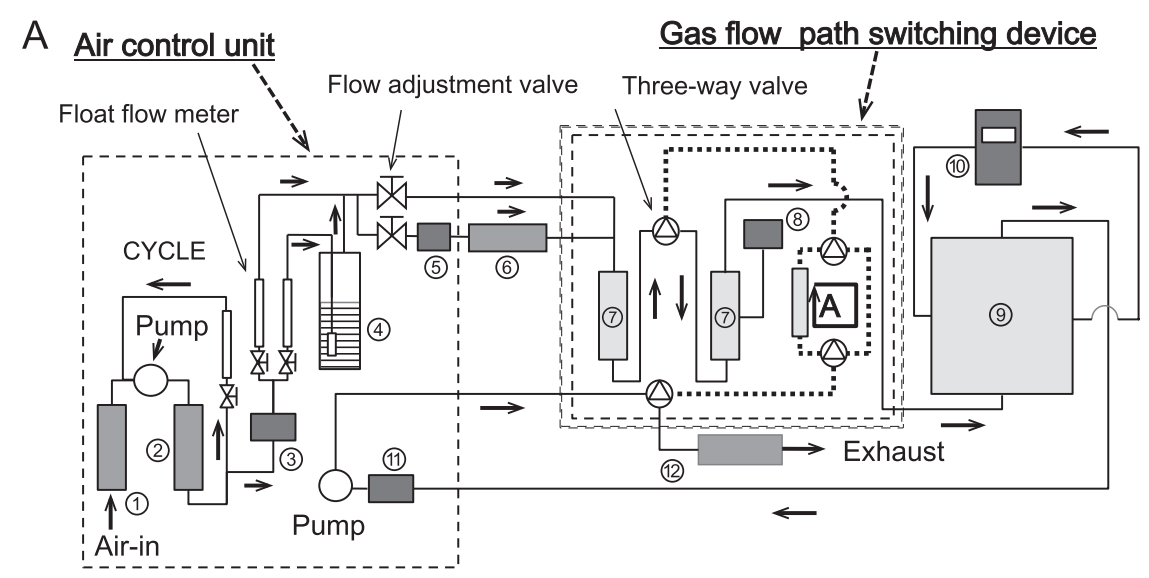

B

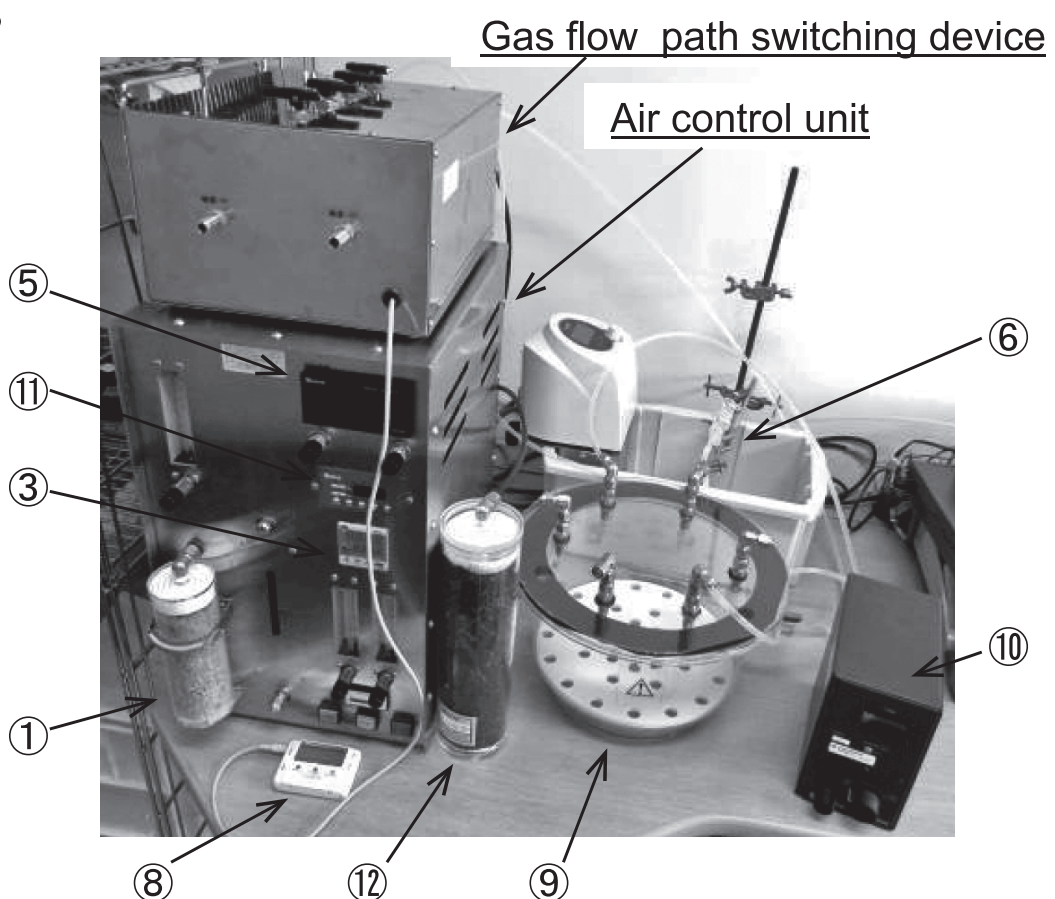

Fig. 1 System for exposing plants to HCHO. Fig. 1A and $1 \mathrm{~B}$ shows the flow diagram of the system and photographs of the system, respectively. The circled numbers indicate the following: (1) Silica-gel column, (2) chemical absorption and active carbon column, (3) mass-flow controller, (4) humidification water tank, (5) mass-flow sensor, (6) formaldehyde generator, (7) gas mixing tank, (8) temperature and humidity meter, (9) exposure chamber, (10) formaldehyde meter, (11) anti-corrosive-gas mass flow controller, (12) formaldehyde chemical absorption column. The boxed A in Fig. 1A indicates the dehumidifier which can be installed when the rates of formaldehyde absorption by plants are measured in a closed chamber system (see text).

ドから遊離される $\mathrm{HCHO}$ の気相中での平衡濃度は $25^{\circ} \mathrm{C}$ 以 上ではほぼ一定になるとされている ${ }^{16)}$.二重破線で囲まれた Gas flow path switching device (特注品, ADTEC
CORPORATION) は, ガスの混合 (7), ガスの温度とRHの

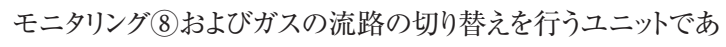
る. 9は供試植物を HCHO に曝露するためのチャンバーで 
ある. チャンバーとしては, ポリカーボネート樹脂製の丸型デシ ケーターの本体部分（直径 $14.5 \mathrm{~cm}$, 容積 $7 \mathrm{~L}$ ）をアクリル 樹脂製の板で盍をして用いた. 10はチャンバー内の HCHO 濃度の測定器で, Interscan 製のホルムアルデヒド測定器 Model 4160 である.この測定器の用いている HCHO 測定 原理は電気化学式定電位電解法に基づく. 測定器は毎分 $1.0 \mathrm{~L}$ のガスを内蔵ポンプによって吸引・吐出しながら連続的 に HCHO 濃度を測定するもので, これによってチャンバー内 のガスの撹拌も行った.

次に本装置によって供試植物に HCHO を含む一定湿度 の空気を曝露し，そののちこの空気を排気するまでの気体の 流れについて説明する. まず空気を(1)のシリカゲル充填力ラム および(2)の化学吸着剤および活性炭充填力ラムを通過させる ことにより, 乾燥および不純物の除去をおこない, Pumpと(3) の Mass-flow sensorによって一定流速で装置内へ送り达 む. Float flow meter で任意の割合で空気を分流し，一方は そのまま, 他方は(4)の Humidification water tankに導入し て加湿する. 加湿空気と乾燥空気を合流させたのち, Flow adjustment valve によって分流し，一方はそのまま，他方は(5) の Mass-flow sensorで流量を調節したのち, (6)の formaldehyde generatorを通過させて HCHO を加える. 両 者を(7)の Gas mixing tank (容量 $0.5 \mathrm{~L}$ )において混合し,さ らにもう一つの同容量の(7)を通して混合する. 混合ガスの温 度とRHは, 8の Temperature and humidity meterによっ て, HCHO 濃度は10の Formaldehyde meter によって, 各々
モニターし, それらのデータを見ながら, 所期の組成になるよ うに，手動で各ガス成分の混合量を調節する. 混合ガスは試 料植物を設置した曝露チャンバー9に導入する.チャンバー から出た混合ガスは, Anti-corrosive-gas mass flow controller とポンプによって所定の量送り出される. これを排 気する前に, (12) Formaldehyde chemical absorption column （Purafil SP と Purakol の 1:1 混合物, Purasil）を通過させ て HCHO をトラップした. なお, (3), (5)およ゙11)の Mass flow controllerのメーカー, 形式, 仕様はそれぞれ, アズビル, MPC9500, F.S. 500 mL min ${ }^{-1} \pm 2 \%$; コフロック, 3810S, F.S. $500 \mathrm{~mL} \mathrm{~min}^{-1} \pm 2 \%$; およびコフロック, 8300, F.S. 500 $\mathrm{mL} \min ^{-1} \pm 1.5 \%$ である.

\section{植物試料}

シロイヌナズナ (Arabidopsis thaliana Col-0) の野生株 （WT）およびWTにHCHO の同化代謝系を導入した形質 転換株 $(\mathrm{AB})^{7)}$ を用いた. 無菌的に寒天培地上で種子を 発芽させ，2-3 週龄（第 8 葉形成期）に達した個体を直径 $5 \mathrm{~cm}$ のビニルポットに鉢上げした. 鉢上げに用いた土壤は, バーミキュライト 2 容とパーライト 1 容の混合物であり, $1 / 1000$ に希釈したハイポネックス（N-P-K=6-10-5）溶液を十分 吸水させて使用した. $2 \sim 3$ 日に一度底面給水を行い, 施肥 は上記と同じハイポネックス溶液を週に一度水の代わりに与え ることによった. 鉢上げ以降は人工気象器内にて $7 \sim 8$ 週歯令 (葉数 20 ～ 25 枚）まで育成した. 花成を遅らせて葉の数を 多くするために, 短日条件（明期 10 時間, 暗期 14 時間）と

A
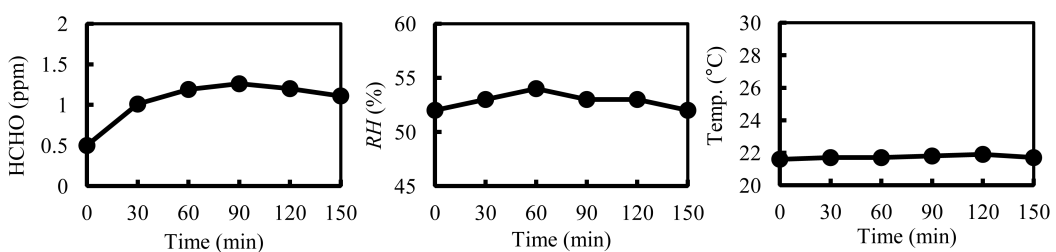

B
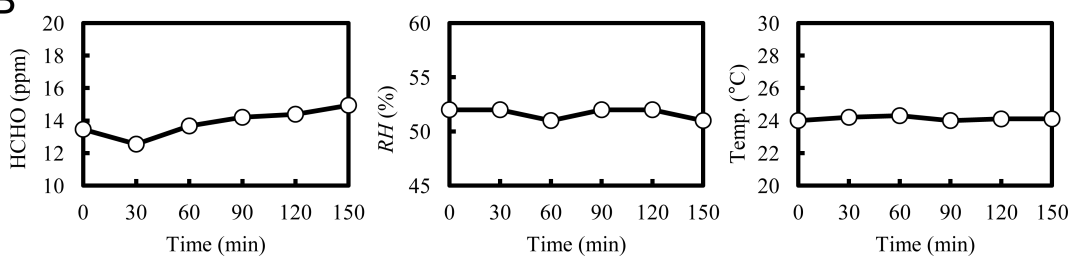

Fig. 2 Performance test of the constructed system. Three pots of wild-type (WT) Arabidopsis thaliana and its transformant (AB) were placed together in the chamber for HCHO exposure for $150 \mathrm{~min}$. The HCHO concentration and humidity $(\mathrm{RH})$ were manually controlled to keep them within a range of 1-2 ppm (A) or 14-16 ppm (B) for $\mathrm{HCHO}$, and $R H$ within 50-55\%. The temperature of the room was set at $22{ }^{\circ} \mathrm{C}$ (for summer seasons) and $24{ }^{\circ} \mathrm{C}$ (for winter seasons) for experiments $\mathrm{A}$ and $\mathrm{B}$, respectively. Experiments were repeated more than three times and the representative data are shown. 

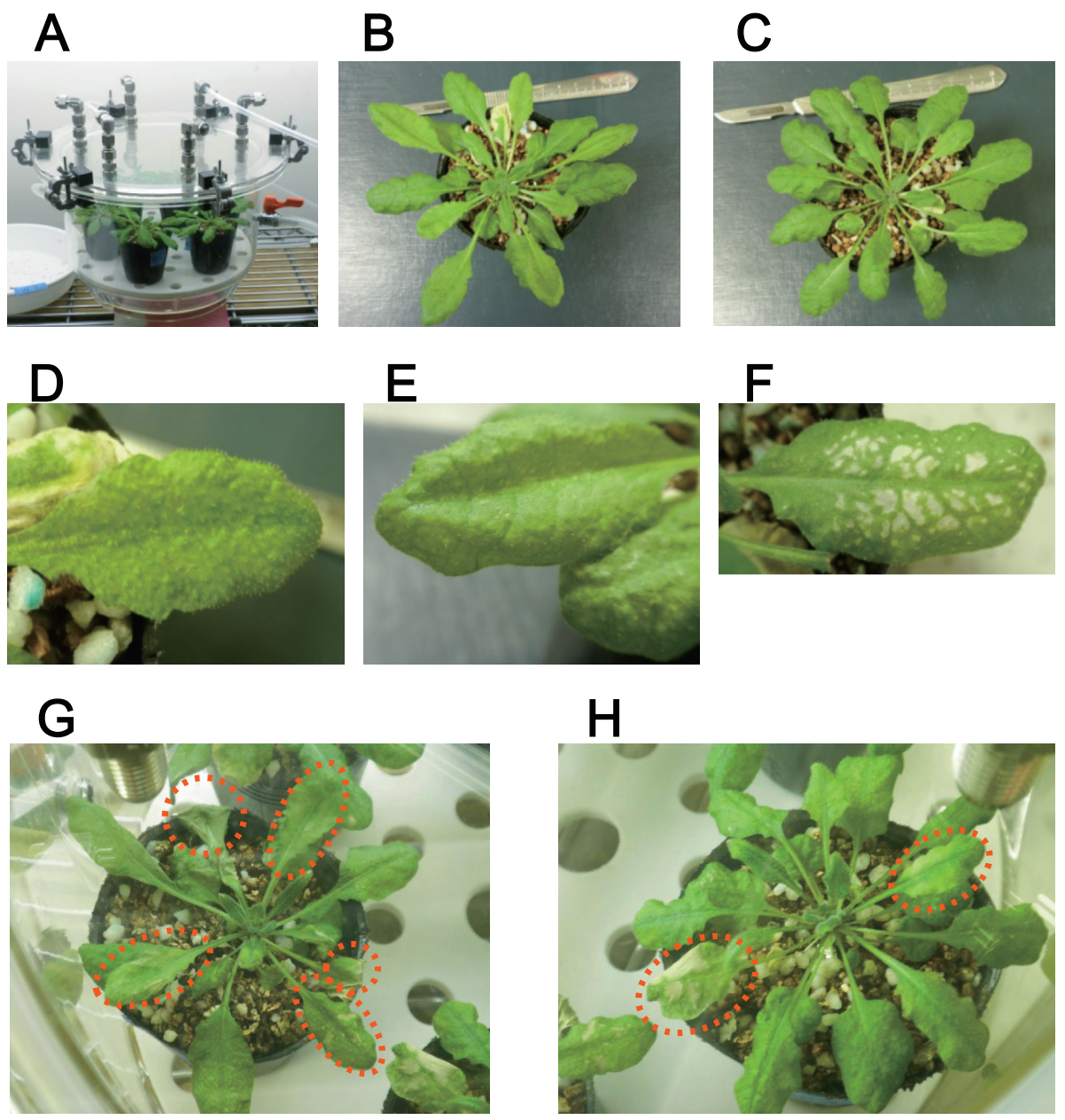

Fig. 3 Effect of $\mathrm{HCHO}$ at low concentration (1-2 ppm) on the wild-type (WT) and the transformant $(\mathrm{AB})$ Arabidopsis thaliana at $22{ }^{\circ} \mathrm{C}$. (A) Overview of the exposure chamber containing six pots of plants. (B) The WT after exposure for 48 hours. (C) $\mathrm{AB}$ after exposure for 48 hours. (D) and (E) Leaf surfaces of the WT deformed after 48-hours exposure. (F) Leaf surface of the WT with bleached patches that appeared after 5 days from the end of the 48 hours exposure. $(G)$ The WT after exposure for 5 days. $(\mathrm{H}) \mathrm{AB}$ after exposure for 5 days. Leaves circled with a red dotted line in $(\mathrm{G})$ and $(\mathrm{H})$ indicate damage after 5 -days of exposure.

し, 蛍光灯照明下 $\left(70 \sim 100 \mu \mathrm{mol} \mathrm{m}^{-2} \mathrm{~s}^{-1}\right)$, 温度は $22^{\circ} \mathrm{C}$ とした。

\section{植物体の HCHO への曝露}

植物体 (WT 株と $\mathrm{AB}$ 株) は, 7-8 週齢のものを, それぞ れ 3 個体合計 6 個体を一緒に曝露チャンバー内に設置し, HCHO 曝露前のプレ順化を 2 日間おこなった. 光源としては 蛍光灯を用い, チャンバーの真上から照射した. 光合成有効 光量子束密度は約 $70 \mu \mathrm{mol} \mathrm{m}^{-2} \mathrm{~s}^{-1}$ であった. $24{ }^{\circ} \mathrm{C}$ たは $22{ }^{\circ} \mathrm{Cにて,} \mathrm{RHを} 50$ 〜 55 \%に調整した空気を毎分 $500 \mathrm{~mL}$
供給してプレ順化とした。この後に底面給水を行った後, $\mathrm{HCHO}$ 曝露を開始した. 曝露条件は, 上記の空気に HCHO の気体を混合し, その濃度を 1 ～ 2 ppm ( 低濃度 ) または $14 〜 16 \mathrm{ppm}$ (高濃度) に調整した気体を用いた以 外はすべて同じとした。曝露時間の詳細は, Fig. 2, Fig. 3 お よび Fig. 4 に記載した.なお, チャンバーでのホルムアルデヒ ド含有ガスの曝露中にかん水は行っていないが, 予備試験で この期間かん水を行わなくても生育には影響がないことは確 認済みである. 


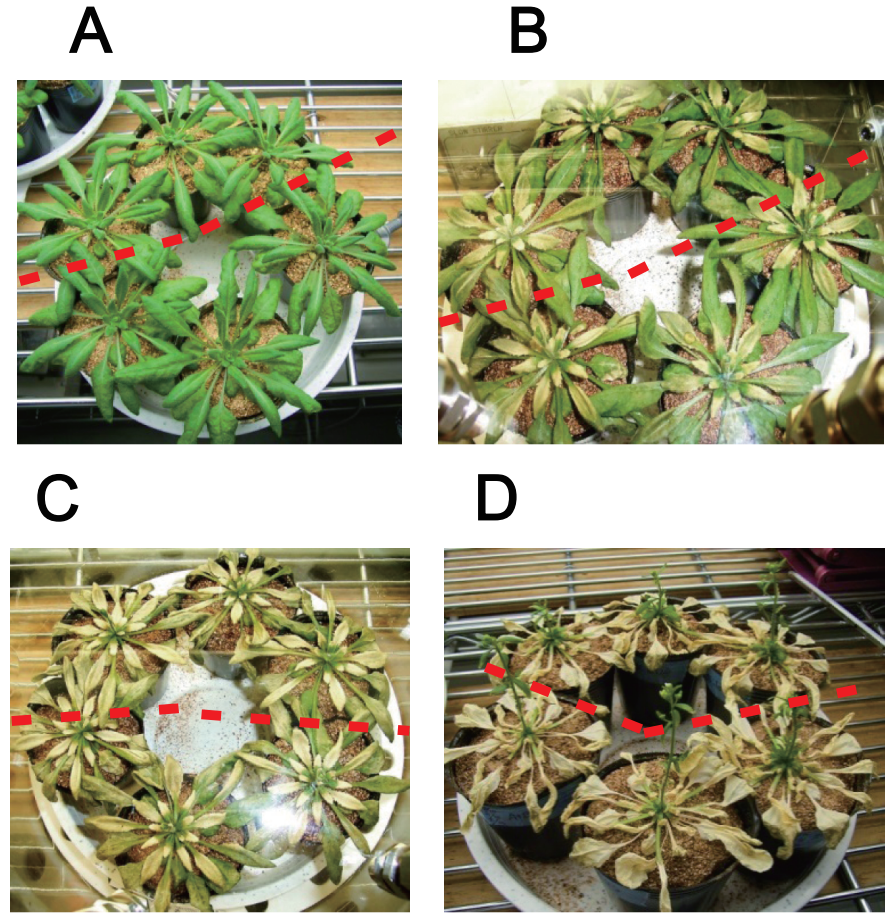

Fig. 4 Effect of $\mathrm{HCHO}$ at high concentration (14-16 ppm) on the wild-type (WT) and the transformant (AB) Arabidopsis thaliana at $24{ }^{\circ} \mathrm{C}$. In (A) to (D), each of the plants above and below the red dotted line are $\mathrm{WT}$ and $\mathrm{AB}$, respectively. (A) Before exposure. (B) and (C) after exposure for 3 and 4 days, respectively. (D) Plants exposed to $\mathrm{HCHO}$ (sample (C)) were further grown under ambient air conditions for 5 days under constant light.

\section{結果および考察}

\section{HCHO 曝露装置の性能試験}

植物材料を曝露チャンバーに設置し, HCHO を加えた空気 を曝露チャンバーに供給し, 一定時間所定の HCHO 濃度お よび所定の湿度に手動で保つことができるかどうかを調べた Fig. 2A および 2B は RHを 50 〜 55 \%に保ちながら, HCHO 濃度をそれぞれ 1 ～ $2 \mathrm{ppm}$ (低濃度) および $14 \sim 16 \mathrm{ppm}$ (高濃度)に 150 分間維持したときのデー夕を示す. 実験は 3 回以上行い, そのうちの代表的なデー夕を示した. 150 分間 における $\mathrm{HCHO}$ および RH の変動は, 低濃度 $\mathrm{HCHO}$ の条

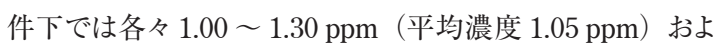
び 52 〜 54 \% (平均 RH 53 \%), また高濃度 $\mathrm{HCHO}$ の条件

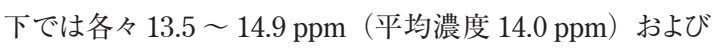
$51 \sim 52 \%$ (平均 RH $52 \%$ ）であった. なお, Fig. $2 \mathrm{~A}$ と $2 \mathrm{~B}$ で温度が異なっているのは, 実験の時期が異なったことによる
(夏季 $22^{\circ} \mathrm{C}$, 冬季 $24^{\circ} \mathrm{C}$ ). 低濃度の $\mathrm{HCHO}$ 一の曝露実験 においては, 開始からほぼ一定のガス環境に達するまで約 30 分間は手動によって湿度と HCHO 濃度の調整を頻繁に行 う必要があったが, これはチャンバーの開閉と植物との接触 開始による環境の急変のためと推測された. それ以降変動幅 は小さくなり, 比較的容易に手動で一定の環境を維持するこ とができた。

曝露時間を 4.5 時間に延長して装置を稼働したときにも, 低 HCHO 濃度条件では HCHO 濃度を $1.10 \sim 1.30 \mathrm{ppm}$ (平均濃度 $1.27 \mathrm{ppm}$ ), $R H$ を $49 \sim 55 \%$ (平均 $50 \%$ ) に 維持し, 高 $\mathrm{HCHO}$ 濃度条件では $\mathrm{HCHO}$ 濃度を 13.8 $14.4 \mathrm{ppm}$ (平均 $14.1 \mathrm{ppm}$ ), $R H$ を $51 \sim 52 \%$ (平均 $R H$ $52 \%$ ）に維持することができた（デー夕は省略）.

供試植物への曝露時間を 4 日間に延長し, HCHO 濃度を $14 \sim 16 \mathrm{ppm}$ に設定した場合は, HCHO 濃度とRH の手動 による調節を日に 2 回行ったが, このときの $\mathrm{HCHO}$ 濃度は $14.2 \sim 16.3 \mathrm{ppm}$ (平均 $15.2 \mathrm{ppm}$ ), $R H$ は $45 \sim 58 \%$ (平 
均 50 \% ) で変動幅がやや大きくなった（デー夕は省略）.

以上の実験から，本システムが所期の性能を有することが 示された.

\section{HCHO 曝露がシロイヌナズナの野生型および組換え体に及 ぼす影響}

この装置を用いて, 1〜 $2 \mathrm{ppm}$ (低濃度) または $14 \sim 16$ $\mathrm{ppm}$ (高濃度) の $\mathrm{HCHO} へ の$ 曝露が, シロイヌナズナの $\mathrm{WT}$ および $\mathrm{AB}^{7)}$ に及ぼす影響について予備試験的に観察し た．それぞれの条件での結果を Fig. 3 および Fig. 4 に示す。

Fig. 3A はWT および $\mathrm{AB}$ を 3 個体ずつ一緒にチャンバー 内に設置した様子を示す. Fig. 3B と $3 \mathrm{C}$ は連続光照射下で 48 時間曝露した後の WT および $\mathrm{AB}$ の個体をそれぞれ示 す.この曝露によって植物体に顕著な変化は見られなかった が, 両個体ともに一部の葉においては, 表面の滑らかさがわ ずかに失われて, 多数の細かな起伏を生じたり（Fig. 3D）, 葉の辺縁部が垂れ下がったものや, 直径 $1 \sim 2 \mathrm{~mm}$ 程度の 薄い白班が現れたりしたものもあった（Fig. 3E).48 時間の 曝露ののち, チャンバーから取り出し, 同一室内に拀いて連 続光下で 1 週間維持したところ, 両株ともすでに生じていた 白班がさらに拡大し明瞭になった（Fig. 3F).

Fig. $3 \mathrm{G}$ と $3 \mathrm{H}$ は，それぞれ $\mathrm{WT}$ と $\mathrm{AB}$ を 5 日間低濃度の $\mathrm{HCHO}$ に曝露したのちの様子を示す. WT および $\mathrm{AB}$ とも に, すべての葉で, 辺縁部が垂れ下がるか波打つ傾向がみ られた. 一部の葉においては, 赫い点線で囲んで示したよう に斑状の白色化がみられた. このように変化した葉の割合が $\mathrm{AB}$ とWTとで明暸に異なっているかどうかについては今後 解析を行う必要がある。両株とも斑紋を生じた葉も枯死するこ とはなかった. 植物体からはその後新しい葉も生じ, 花茎も形 成され結実した (デー夕は省略)。このように比較的低濃度 (1 2 $2 \mathrm{ppm})$ の $\mathrm{HCHO} へ の$ 曝露でも 48 時間以上に及ぶと 可視的な傷害がおこることが明らかになった.

次にWT および $\mathrm{AB}$ を 3 個体ずつ連続光照射下で高濃度 の $\mathrm{HCHO}$ に長時間曝露したときの影響を調べた（Fig. 4). 両株とも 2 日間の曝露では顕著な変化は認められなかった が, 3 日後には比較的小さく若い葉において, 顕著な褐変が みられ，4日後には, 茎頂を含む先端の一部分以外の葉は薄 緑色がかった褐色となった. このようにWTと AB 両方に同様 の変化がみられ感受性の明確な違いは見られなかった，両株 とも傷害を受けた葉は枯死したが植物体自体の死滅にはいた らず, その後茎頂から正常な花茎が生じ (Fig. 4D) 結実し た。

\section{シロイヌナズナのガス状 HCHO に対する感受性}

われわれの以前の研究では, シロイヌナズナの芽生えを容 器内で寒天培地上に生育させた場合, WT は寒天培地中の

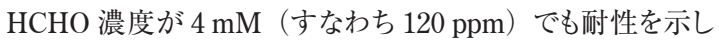

$8 \mathrm{mM}$ では生育不能であったのに対して $\mathrm{AB}$ では $8 \mathrm{mM}$ でも 耐性を示した. この場合, $\mathrm{HCHO}$ は根から吸収され, $\mathrm{AB}$ で は葉で発現している HCHO の同化経路によって無害化され ていると考えられた ${ }^{7)}$. これに対して, 今回初めて, 十分成長 したシロイヌナズナを一定の既知の濃度のガス状の $\mathrm{HCHO}$ に 曝露したところ, 1〜 $2 \mathrm{ppm}$ の $\mathrm{HCHO}$ に対しても, 48 時間の 曝露で, $\mathrm{WT}$ 株および $\mathrm{AB}$ 株ともに一部の葉の表面に傷害が みられ, シロイヌナズナがガス状の $\mathrm{HCHO}$ に対して水溶液状 の $\mathrm{HCHO}$ よりも高い感受性をもつことが示唆された.これは $\mathrm{HCHO}$ が強く水和するため, 水溶液状ではその遊離状態の HCHO 濃度が極めて低くなるためと説明できるかもしれない. したがって, WT と $\mathrm{AB}$ の間で $\mathrm{HCHO}$ 耐性に差が出るのは 気相に打ける濃度がさらに低い場合である可能性がある. ま た, 過去の水溶液状の $\mathrm{HCHO}$ を与えた実験と本実験とでは 用いた植物個体の生長期が異なるため, そのことによる影響 も考慮しなければならない。

\section{本曝露装置の有用性}

湿度を一定に保ちながら一定の濃度のガス状 $\mathrm{HCHO}$ を供 給するシステムの作成は, HCHO が植物に及ぼす影響を明 らかにし, 植物の $\mathrm{HCHO}$ 浄化能を定量的に調べるうえで必 要である. シロイヌナズナのような小型の植物用に小型の曝露 チャンバーを設計する場合, チャンバー内ガス濃度等の変動 が大きくなりやすいと予想されるため, HCHO を一定時間トラ ップして測定する方法（例えば Kondo et al. ${ }^{13,14)}$ ) は採用で きず, リアルタイムに HCHO 濃度を測定し迅速から正確に調 整することが求められる. 本論文に使用したシステムは暴露 条件を自動的に維持できるものではないが, 迅速な調整を可 能にするための特徴を持たせた. たとえば，空気を加湿する とき, 乾燥空気をバブルさせる水の温度でそれを制御すること が行われているが, 本研究で行われたように, バイパスしてき た乾燥空気と混合する方法が迅速な制御に必要と思われる. また, 本研究では, 固体のパラホルムアルデヒドからの $\mathrm{HCHO}$ の昇華がある温度以上では一定の分圧になるという保利らの 知見 (例えば Hori et al. ${ }^{16)}$ ) と示唆に基づいて, より簡便で 安全なシステムを構築した。

我々は, 現在, 植物が低濃度（1２ppm）および高濃 度 $(14 \sim 16 \mathrm{ppm})$ の $\mathrm{HCHO}$ に曝露されたときの応答をトラン スクリプトーム解析によって明らかにすることを目指しており, 本 装置をこの解析に利用している.

\section{今後の改良点}

供試植物の $\mathrm{HCHO}$ 吸収速度をリアルタイムで測定するた めには，曝露チャンバー内のガスの流路を閉鎖系としてガスを 循環させて, ガス中の HCHO 濃度をモニターすることが必要 である.この場合に提案されるガス流路を Fig. 1Aには二重 破線で囲まれた領域内に点線で示した.〈わえて, 植物による 
蒸散活動のために, 曝露チャンバー内の $R H$ が急速に上昇 すると予想される. 実際に本暴露チャンバーで測定したとこ ろ, 曝露チャンバー内の $R H$ は 20-30 分で 90 \%以上となっ た.したがって, RHを 50-60\%に維持しつつ測定するために は, HCHO を除去せず水分のみを除去するためのデバイス が必要となる（Fig. 1AにおけるA）。このようなデバイスを開 発することにより, 植物に対する HCHO の影響に関する基礎 的知見を集積することが今後必要である.

\section{摘 要}

ホルムアルデヒド（HCHO） は重要な産業用化学物質であ るが, 大気や室内の環境污染物質でもあり, 化学物質過敏 症やシックハウス症候群の原因物質の一つとされている. わ れわれは, 先に, HCHO を固定して同化する酵素群の遺伝 子をメチロトローフ細菌から取得し, これを導入することによっ て, 植物に HCHO の同化能を付与することに成功した. この 方法を観葉植物などに適用して環境浄化（ファイトレメデイエ ーション）に役立てることができるかどうかを検討するために は, 遺伝子導入によって付与された HCHO の吸収能や $\mathrm{HCHO}$ への耐性について, より定量的なデータが必要とされ る. 本論文においては, 一定の湿度を保ちながら, 種々の濃 度のガス状 HCHO に植物を曝露するためのシステムの作成 とその性能について報告した. 予備試験的に, このシステムを 用いてシロイヌナズナの野生型および上記の形質転換体を HCHO に曝露したときの可視的影響を観察した. 両植物体と もに, $1 \sim 2 \mathrm{ppm}$ にて 48 時間の曝露では葉に可視的な傷害 がみられ, $14 \sim 16 \mathrm{ppm}$ で 4 日間の曝露では成葉が全面的 に褐変した. しかし曝露後通常大気中で栽培をつづけると茎 頂から成長が再開され死滅はしていなかった.

\section{謝辞}

本装置の構築にあたって, ADTEC COPRPORATION 社 (神奈川) の鈴木アトム氏に曝露装置の主要部分の作成に ついて多大のご協力をいただき, JMS 社（東京）の東出和 聡氏には HCHO の計測機器について有益なお教えをいただ いた. 有限会社アキツ計測の正木美登史氏にサンプル空気 除湿装置の作成について多大のご協力をいただいた. また, 金沢星稜大学の大薮多可志教授と産業医科大学の保利一 教授および石田尾徹講師には, HCHO 曝露装置や設備を 見学させていただき有益な助言をいただいた. HCHOへの 曝露による ROS 発生については東京理科大学・朽津和幸 教授のご指導をいただいた. 本研究の一部は文部科学省科 学研究費補助金, 基盤研究（B）19380186（代表者 泉
井桂）による支援を受けた.

\section{参考文献}

1) 中西準子, 鈴木一寿. ホルムアルデヒド（詳細リスク評 価書シリーズ 17). NEDO 技術開発機構, 産総研化学 物質リスク管理研究センター共編, 丸善, 東京. 1-200. 2009.

2) Kaden DA, Mandin C, Nielsen GD, Wolkoff P. Formaldehyde. In: WHO guidelines for indoor air quality: selected pollutants, WHO, Geneva. 103-156. 2011.

3) Wolverton BC. How to grow fresh air. Penguin Books, New York. 1-144. 1997.

4) Wolverton BC, Wolverton JD. Plants and soil microorganisms - Removal of formaldehyde, xylene, and ammonia from the indoor environment. J. Miss. Acad. Sci. 38: 11-15. 1993.

5) Kato N, Yurimoto H, Thauer RK. The physiological role of the ribulose monophosphate pathway in bacteria and archaea. Biosci. Biotech. Bioch. 70: 1021. 2006.

6) Sawada A, Oyabu T, Chen LM, Li KZ, Hirai N, Yurimoto H, Orita I, Sakai Y, Kato N, Izui K. Purification capability of tobacco transformed with enzymes from a methylotrophic bacterium for formaldehyde. Int. J. Phytoremediat. 9: 487-496. 2007. Erratum in: Int. J. Phytoremediat. 10:598. 2008.

7) Chen LM, Yurimoto H, Li KZ, Orita I, Akita M, Kato N, Sakai, Y, Izui K. Assimilation of formaldehyde in transgenic plants due to the introduction of the bacterial ribulose monophosphate pathway genes. Biosci. Biotech. Bioch. 74: 627-635. 2010.

8) Song Z, Orita I, Yin F, Yurimoto H, Kato N, Sakai Y, Izui K, Li K, Chen LM. Overexpression of an HPS/ PHI fusion enzyme from Mycobacterium gastri in chloroplasts of geranium enhances its ability to assimilate and phytoremediate formaldehyde. Biotechnol. Lett. 32: 1541-1548. 2010.

9) 泉井桂, 陳麗梅, 加藤暢夫, 阪井康能, 由里本博也, ホルムアルデヒドに対する耐性を植物に付与する方法, 環境中のホルムアルデヒドを植物に吸収させる方法 . 特 許第 4487071 号, 2010 年 4 月 9 日.

10) Izui K, Chen LM, Kato N, Sakai Y, Yurimoto H. Method to confer formaldehyde-resistance to a plant, and a method to have a plant absorb environmental formaldehyde. United States Patent. Patent No.: US 7,973,222 B1. Date of Patent Jul. 5, 2011.

11) Wang SS, Song ZB, Sun Z, Zhang J, Mei Y, Nian H-J, Li KZ, Chen LM. Effect of formaldehyde stress on physiological characteristics and gene expression associated with photosynthesis in Arabidopsis thaliana. Plant Mol. Biol. Rep. 30: 1291-1302. 2012. 
12) Park MA, Seo JH, Park JS, Kwon M. Proteomic identification of toxic volatile organic compoundresponsive proteins in Arabidopsis thaliana. Plant Cell Rep. 28: 1603-1614. 2009.

13) Kondo $T$, Hasegawa $K$, Uchida R, Onishi M, Mizukami A., Omasa K. Absorption of formaldehyde by oleander (Nerium indicum). Environ. Sci. Technol. 29: 2901-2903. 1995.

14) Kondo $T$, Hasegawa $K$, Uchida $R$, Onishi $M$, Mizukami A, Omasa K. Absorption of atmospheric formaldehyde by deciduous broad-leaved, evergreen broad-leaved, and coniferous tree species. B. Chem. Soc. Japan. 69: 3673-3679. 1996.

15) $\mathrm{Xu} \mathrm{Z}$, Wang L, Hou H. Formaldehyde removal by potted plant-soil systems. J. Hazard. Mater. 192: 314-318. 2011.

16) Hori H, Arashidani K. Basic characteristics of a formaldehyde gas generator using solid paraformaldehyde. J. Univ. Occup. Environ. Health 19: 123-131. 1997. 